\title{
Comparative Analysis of Attitudes toward a Festive Event between Local Merchants and Residents - Music Festival at Fulong Beach, Taiwan
}

\author{
Chung-Tai $\mathrm{Wu}^{1, *}$, Huey-Ling Liao ${ }^{2}$ \\ ${ }^{I}$ Department of Tourism \& Leisure Management, Lee-Ming Institute of Technology, Taiwan \\ ${ }^{2}$ Department of Food \& Beverage Management, Lee-Ming Institute of Technology, Taiwan
}

*Corresponding Author: Chung-Tai Wu, Department of Tourism \& Leisure Management, Lee-Ming Institute of Technology, Taiwan

\begin{abstract}
The study compares the difference of attitude between local business residents (merchants) and non-business operating residents toward the annual music festival in Fulong Beach, Taiwan. Attitudes were evaluated across four dimensions: financial benefit, image implication, environmental impact, and local support. The sample came from 75 local merchants and 77 residents. It was identified that residents felt more strongly of "image implication" but merchants were more "supportive" of the festival. Although statistically insignificant, local residents were more concerned about "environmental impact" associated with the festival. The attitude toward "financial benefit" is about even between merchants and residents. Female merchants felt the festival brought "financial benefit" to the community more than their male counterparts did. Female merchants also were more "supportive" of the festival than their male counterparts did. Merchants who were more educated felt more strongly toward the host of the festival in "financial benefit", "image implication", and "local support". However, highly educated merchants were also more concerned about "environmental impact" associated with the festival. It was not a surprise that merchants who earned more were also more "supportive" of the festival. Female residents felt more highly of "financial benefit" than male residents did. Less-educated local residents felt more highly of "image implication" from the festival than more highlyeducated residents did.
\end{abstract}

Keywords: Environmental Impact, Financial Benefit, Image Effect, Local Support

\section{INTRODUCTION}

Mega events and festivals have continuously played a key role in community based-tourism development (Getz, 1991). There are many reasons for hosting events or festivals, to name a few, such as creating a positive image of a place, contributing to sustainable development, fostering better hostguest relations; preserving sensitive natural/social/cultural environments, bringing in money to the local community (Uysal et al., 1993; Small et al., 2005). The primary reason for staging a festival is likely the opportunity to have financial gains (Mayfield \& Crompton, 1995). Given the fact that hosting an event or festival is a way to increase demand for a tourism destination, economic impacts of festivals can be simultaneously positive and negative (Brown et al., 2002), as well as spatial distribution of expenditures (Long \& Perdue, 1990).

Although exaggeration of financial benefits (i.e. nonlocal spending from the host community) may not deter communities from hosting an event or festival, social costs (e.g. increased traffic, increased crime, and congestion on local service) and/or environmental impact associated with an event or festival may be causes for concern from scholars, organizers, visitors, and residents (Delamere, 2001; Fredline et al., 2002; Gursoy et al., 2004; Kim \& Petrick, 2005; Kim et al., 2006; Andersson \& Lundberg, 2003; Tang et al., 2005; Jackson, 2008; Kim \& Uysal, 2008; Gibson \& Stewart, 2009; Yolal et al., 2009; Zhou \& Ap, 2009; Laing \& Frost, 2010; Chen, 2011; Gibson \& Wong, 2011; Song et al., 2012; Collins \& Cooper, 2017). Extensive debate has been focused on the perceptions of residents (Kim \& Petrick, 2005). Tourism resource development, tourism infrastructure development, facility revitalization, image enhancement, economic benefits, and interest in foreign cultures are typical positive impacts for hosting events or festivals. Conversely, negative impacts may include negative economic perspectives (e.g. increased real estate costs), disorder/conflicts, and traffic congestion. 
Historically, academic papers have studied events and festivals on evaluating their economic impact, social/cultural impact, environmental impact separately (Getz, 2010; Gibson \& Wong, 2011; Mair \& Whitford, 2013). At the same time, perceptions of events and festivals have mostly been studied separately on organizers, visitors, and residents, (Gursoy et al., 2004; Kim \& Petrick, 2005; Kim et al., 2006; Song et al., 2012). The paper attempts to study the difference of attitudes toward a festival between local merchants and residents. Subjects' perceptions toward a festive event would be evaluated across both positives and negatives of economic impact, social/culture impact, and environmental impact.

\section{LITERATURE REVIEW}

Numerous studies on residents' perceptions toward an event or festival have been conducted. Contexts applying the issue include economic impact, social/cultural impact, and environmental impact. A brief review to the major studies is as follows:

Fredline et al. (2002) identified six dimensions of social impacts associated with events: "social and economic development benefits", "concerns about justice and inconvenience", "impact on public facilities", "impacts on behavior and environment", "long-term impact on community", and "impact on prices of some goods and services". Social and economic development benefits would include: "event provides opportunities for people to have fun with their family and friends", "event entertains local residents and gives them an opportunity to attend a major international event", "event gives residents an opportunity to show other people how special their community is", "event promotes values that are good", "money that tourists spend when they come to the event helps to stimulate the economy", "event enhances Victoria's reputation", "media coverage of the event promotes tourism and business development", "increased skill base for event management in Melbourne", "pride that residence have in the city", "opportunities to meet new people", "entertainment opportunities", "range of interesting things to do", "interactions between locals and tourists", "opportunities for local business", and "friends come and visit because of the event".

Concerns about justice and inconvenience would include: "the rights and civil liberties of local residents", "event disrupts the lives of local residents and causes them stress", "noise levels", "traffic congestion in the vicinity of the event precinct", "ordinary residents get no say in the planning and management of the event", "public money spent on the event would be better spent on other things", "parking availability in the vicinity of the event precinct", and "event increases social inequity because it provides benefits to the rich but none to the poor". Impact on public facilities would include: "maintenance of public facilities", "appearance of area around event precinct", "employment opportunities", "public transport", "facilities available to local residents", and "number of people in the area around the event precinct". Impacts on behavior and environment would include: "rowdy and delinquent behavior", "excessive drinking and/or drug use", "Litter in the vicinity of the event precinct", "crime levels", and "damage to the environment". Long-term impact on community would include: "number of people moving in permanently or buying holiday homes", "turnover for local businesses", and "social and moral values". Impact on prices of some goods and services would include: "overall cost of living", "prices of some goods and services", and "property values in the vicinity of the event precinct".

Gursoy et al. (2004) proposed a four-factor structure of perceived social-economic impact for hosting an event or festival: "community cohesiveness", "economic benefits", "social incentives", and "social costs". Community cohesiveness would include: "generate revenues for civic projects", "enhance community image", "build community pride", "help preserve the local culture", and "help create cohesion in the community". Economic benefits would include: "increase employment opportunities", "increase standard of living", and "encourage locals to develop new facilities". Social incentives would include: "provide more recreational opportunities", "promote organizations and business", "offer family based recreation activities", "enhance community image to outsiders", "help foster relationship between residents and visitors", and "educational (make people aware)".

From the proposed Social Impact Perception (SIP) scale by Small et al. (2005), community impacts include: "difficulty finding car parking", "traffic congestion", "crowding in local shops and facilities", "public transport services congested", "noise pollution", "increased range of goods and services", "increased price of goods and services", "increased job opportunities", "increased business 
opportunities", and "increased local pride". Leisure/recreation impacts include: "increased entertainment opportunities" and "increased future use of existing recreational and leisure facilities". Infrastructure impacts include: "restoration of existing public buildings and public facilities being maintained at a high standard". Health and safety impacts include "increased police presence" and "increased crime and vandalism". Cultural impacts include: "impacts on local character of the community", "impacts on the region's cultural identity", "increased local interest in the region's culture and history", "increased local awareness of the cultural activities available", and "educational experience offered from interaction with visitors".

Kim and Petrick (2005) investigated resident's perceptions on impacts of the 2002 World Cup, where 22 positive impact items were factor analyzed to produce five dimensions while three dimensions were produced from 9 negative impact items. Five dimensions of positive impacts are: "tourism resource development and urban revitalization", "image enhancement and consolidation", "economic benefits", "interest in foreign countries or their cultures", and "tourism infrastructure development". Three dimensions of negative impacts are: "negative economic perspective", "disorder and conflicts", and "traffic problem and congestion".

Kim et al. (2006) evaluated impacts of environmental values on motivation of attending International Festival of Environmental Film and Video (FICA) in the city of Goias, Brazil. Five identified motivations are: "family togetherness", "socialization", "site attraction", "festival attraction", and "escape from routine". "Family togetherness" was composed of "visiting friends and relatives", "spending time with someone special", "bring family closer together", and "family could do something special". "Socialization" included "enjoying festival crowds", "being with people of similar interest", "meeting new people from different places", and "being with friends". "Site attraction" included "a good opportunity to visit Goias", "enjoying historical sights at Goias", and "increase knowledge of local culture at Goias". "Festival attraction" included "enjoying environmental related films", "concerned with environmental issues", "I like films", "learning about nature". "Escape from routine" included "to get away from the demands of life", "to have a change from daily routine", and "to enjoy the night life".

Zhou and Ap (2009) identified four dimensions of residents' perceptions toward impacts of the 2008 Olympic Games: "economic", "social life", "urban development", and "social-psychological". Economic impact includes: "increase business opportunities" and "increase employment opportunities". Social life impact includes: "overcrowding of using facilities during the Games", "inconvenience for local residents due to increased traffic congestion", "higher price levels in Beijing", "more noise which will annoy local residents", "damage the natural environment", "disrupt Beijing residents' peace and tranquility", and "higher levels of crime in Beijing". Urban development impact includes: "enhance Beijing's international identity by world media exposure", "improved city appearance", "the development of new public facilities which can be used by locals", and "improved road condition in Beijing". Social-psychological impact includes: "bring the community closer together", "provide local residents an opportunity to attend an international event", "increase the pride of local residents in the city", "promote Beijing as a tourism destination", "give Beijing a chance to show the world that we're capable of doing", "help people understand different people and cultures", and "give residents a chance to meet new people".

Chen (2011) factor analyzed residents' perceptions toward the impact of annual events in Macao. Seven identified perceptions are: "community pride", "personal gains", "economic benefits", "community life quality", "environmental negatives", "cultural negatives", and "social services pressures". Community pride would include: "increased the city's tourism image", "increased the city's image", "made residents proud in Macao", "gained a sense of pride through these events", "events have made the city more international", "events have contributed to the city's tourism", "events have created more network opportunities for residents", and "events have promoted economic development". Personal gains would include: "events have brought in a big audience", "residents had lots of enjoyment", "events have brought excitement to residents' life", and "events have brought emotional experience to residents' life". Economic benefits would include: "events have raised employment rate", "events have created profits for the government", "events have improved shopping opportunities", "events have created profits for the enterprise", "events have led to the creation of new facilities", and "events have improved overall living standards of the residents". Community life 
quality would include: "events have created many leisure opportunities", "events have created new family-based leisure opportunities", and "events have provided opportunities for residents to learn about their own community". Environmental negatives would include: "events have destroyed the natural environment" and "events have created air pollution". Cultural negatives would include: "events have damaged heritage sites" and "events have disrupted normal life". Social services pressures would include: "events have created traffic jams" and "events have put pressure on urban services".

Song et al. (2012) identified ten environmentally friendly perceptions the festival visitors consider in their decision-making process. They are: "environmental concerns", "perceived customer effectiveness", "attitude", "subjective norm", "positive anticipated emotion", "negative anticipated emotion", "perceived behavioral control", "environmentally friendly tourism behaviors", "desire", and "behavioral intention".

Andersson and Lundberg (2013) proposed a model of total festival impact that is consisted of economic impact, social/cultural impact, and environmental impact. Economic impact includes: "direct expenditure: and "opportunity cost". Social/cultural impact includes: "option value", "bequest value", and "existence value". Environmental impact includes: " $\mathrm{CO}_{2}$ equivalents" and "ecological footprint".

\section{MeTHOdOLOGY}

The literature review provided the bases of constructing the questionnaire. Four dimensions were established: "financial benefit", "image implication", "environmental impact", and "social support". Intentionally omitted in the questionnaire is the dimension of "social impact" because the study seeks to identify the difference of attitudes between local merchants and residents whereas items of "social impact", such as "to have fun with family and friends" and "allowing locals the opportunity to attend a major event", do not seem to differentiate perceptional difference between local "business persons (merchants)" and "non-business residents". In other words, the dimension of "social impact" may vary across demographics such as gender, age, marriage ... etc but logically being indifferent between "merchants" and "residents".

Included in the questionnaire, the first dimension "financial benefit" includes 6 items in the positive direction and 2 items in the negative direction (reverse measures). The concept of these eight items came from Fredline et al. (2002); Gursoy et al. (2004); Small et al. (2005), Kim and Petrick (2005), Zhou and Ap (2009), Chen (2011), Song et al. (2012), and Andersson and Lundberg (2013). The six positive items are: "increased income", "increased economy", "increased employment opportunity", "increased tax revenue", "improved living condition", and "improved public facilities". The two negative items (reversed scale) are: "increased real estate cost (R)" and "increased living expense (R)". When the returned questionnaires are being rated on a five-point Likert-type scale, ranging from 1 (strongly disagree) to 5 (strongly agree)", negative items (R) would be reversed (i.e. " 5 " becoming " 1 ", " 4 " becoming " 2 " ...etc) in the SPSS 20.0 statistical software for Windows.

The second dimension "image implication" includes 6 items in the positive direction and 4 items in the negative direction (reverse measures). The concept of these ten items came from Fredline et al. (2002); Gursoy et al. (2004); Kim and Petrick (2005), Zhou and Ap (2009), and Chen (2011). The six positive items are: "enhanced local image", "enhanced reputation", "enhanced local pride", "increased public security", "improved confidence and pride" and "enhanced leisure facilities". The four negative items (reversed scale) are: "confrontation between tourists and locals (R)", "increased deterioration to the environment", "negative effect on the local youths (R)", and "increased crimes (R)".

The third dimension "environmental impact" is composed of 9 negative items (all measures being reversed) that were conceptualized from Fredline et al. (2002), Small et al. (2005), Chen (2011), Song et al. (2012), and Andersson and Lundberg (2013). These designed nine items are: "unbearable crowding (R)", "deteriorated landscape (R)", "negative effect on natural environment (R)", "increased air pollution (R)", "increased noise (R)", "increased trash (R)", "increased traffic (R)", "satisfies local politician's ambition $(\mathrm{R})$ ", and "negative allocation of facility from crowd" (R)".

The last dimension "local support" consists 6 items (all in a positive direction). The concept of the items came from ideas of Fredline et al. (2002), Gursoy et al. (2004), Kim et al. (2006), Zhou and Ap (2009), and Chen (2011). These sic items are: "I support this festive event", "I support the 
development of this event", "I support more promotion of this event", "local officials should use this event to attract more tourist", "the event should be used as the focal direction of the local's development", and "overall, the event's positives far outweigh the negatives".

After formulation of the questionnaire, 200 copies of the questionnaires were distributed to the locals of Fulong in Taiwan. Situated at the northeast corner of the Taiwan Island, Fulong $\left(122^{\circ} \mathrm{E}, 25^{\circ} \mathrm{N}\right)$ attracts many thousands of visitors annually during its famous music festival in Fulong Beach. The survey took place from July $29^{\text {th }}$ to August $5^{\text {th }}$ of 2017 , immediately after the music festival ended. Both non-business local residents and business-operating locals were the subject of survey. From 200 returned surveys, only 75 returns by the local merchants were deemed valid and 77 returns by the non-business operating local residents were deemed valid, thereby $76 \%$ valid return. As shown in Table 1 , males represent $56 \%(n=42)$ of the merchant respondents, $44 \%$ by the female merchants $(n$ $=33)$. From the non-business local residents, females represented nearly 52\% $(n=40)$ while males represented around $48 \%(n=37)$. By age, majority of the respondents came from the age group of 30 to 50 years old ( $n=37$ for both merchants and residents). However, the next most representatives came from people over 50 years old for merchants $(n=25$ out of 75$)$ while people under 30 years old represented more for non-business local residents $(n=30$ out of 77$)$. By education, majority of the local merchants are less-educated (high school or less at 58.7\%) while majority of the non-business locals are college-educated (62.3\%). By annual income, most of the responding local merchants earn NT $\$ 400,000-\operatorname{NT} \$ 600,000(n=31$ out of 75$)$ or more than NT $\$ 600,000(n=30$ out of 75$)$, while most of the non-business local residents earn less than NT $\$ 400,000(n=38$ out of 77$)$ or NT $\$ 400,000$ $-\mathrm{NT} \$ 600,000(n=32$ out of 77$)$.

Table1. Demographic characteristics of the respondents

\begin{tabular}{|c|c|c|c|}
\hline \multicolumn{2}{|r|}{ Demographics } & Number & Percentage \\
\hline \multicolumn{2}{|r|}{ Type of locals } & & \\
\hline \multicolumn{2}{|c|}{ Local merchants } & 75 & 49.34 \\
\hline \multicolumn{2}{|c|}{ Local residents } & 77 & 50.66 \\
\hline \multicolumn{4}{|c|}{ Gender } \\
\hline \multirow[t]{2}{*}{ Merchants } & Male & 42 & 56.00 \\
\hline & Female & 33 & 44.00 \\
\hline \multirow[t]{2}{*}{ Residents } & Male & 37 & 48.05 \\
\hline & Female & 40 & 51.95 \\
\hline \multirow{4}{*}{ Merchants } & Age & & \\
\hline & Under 30 & 13 & 17.33 \\
\hline & 30 to 50 & 37 & 49.33 \\
\hline & Over 50 & 25 & 33.33 \\
\hline \multirow[t]{3}{*}{ Residents } & Under 30 & 30 & 38.96 \\
\hline & 30 to 50 & 37 & 48.05 \\
\hline & Over 50 & 10 & 12.99 \\
\hline & Education & & \\
\hline \multirow[t]{3}{*}{ Merchants } & High school or less & 44 & 58.67 \\
\hline & 4-year college & 27 & 36.00 \\
\hline & Post graduate & 4 & 5.33 \\
\hline \multirow[t]{3}{*}{ Residents } & High school or less & 27 & 35.06 \\
\hline & 4-year college & 48 & 62.34 \\
\hline & Post graduate & 2 & 2.60 \\
\hline \multirow{4}{*}{ Merchants } & Annual income & & \\
\hline & Under NT $\$ 400,000$ & 14 & 18.67 \\
\hline & NT $\$ 400,000-$ NT $\$ 600,000$ & 31 & 41.33 \\
\hline & Over NT\$600,000 & 30 & 40.00 \\
\hline \multirow[t]{3}{*}{ Residents } & Under NT $\$ 400,000$ & 38 & 49.35 \\
\hline & NT $\$ 400,000-$ NT $\$ 600,000$ & 32 & 41.56 \\
\hline & Over NT $\$ 600,000$ & 7 & 9.09 \\
\hline
\end{tabular}

\section{RESULTS AND DISCUSSION}

As shown in Table 2, local merchants indicated slightly higher mean toward "Q1 increased income" due to Fulong Music Festival than local residents did $(M=3.49>3.40)$. However, local residents 
indicated higher mean toward "Q2 increased economy" than local merchants did $(M=3.74>3.27)$. It must be noted that the standard deviation (S.D.) is the higher for this item (Q2) from merchants, indicating the greatest disparity of attitude among merchants. Merchants indicated higher means toward "Q3 increased employment opportunity", "Q5 improved living condition", and "Q6 improved public facilities" than residents did. In "Q4 increased tax revenue", local residents indicated higher mean than merchants did. For the two remain reversed items, merchants indicated higher mean in "Q7 $(\mathrm{R})$ increased real estate cost" than residents $\operatorname{did}(M=3.29>3.08)$, implying that merchants felt more strongly toward financial penalty from the event. It is noted that all reversed items would be calculated from deduction of 5 in SPSS. Thus, the mean by merchants would be 1.71 instead of 3.29. Likewise, the reversed mean by residents would be 1.92 instead of 3.08. In the last item of the dimension, local residents indicated higher mean in "Q8 (R) increased living expense" than merchants $\operatorname{did}(M=3.19>3.03)$, implying that local residents felt higher living expenditure than local merchants did. Similarly, reversed calculation would render $M=1.97$ instead of 3.03 by merchants, and $M=1.81$ instead of 3.19 by residents.

Table2. Respondents' attitudes toward "financial benefit"

\begin{tabular}{|l|c|c|c|c|}
\hline \multicolumn{1}{|c|}{ Items of measurement } & \multicolumn{2}{c|}{ Merchants } & \multicolumn{2}{c|}{ Residents } \\
\cline { 2 - 5 } & Mean & S.D. & Mean & S.D. \\
\hline Q1. Increased income & 3.49 & 1.018 & 3.40 & 0.892 \\
\hline Q2. Increased economy & 3.27 & 1.308 & 3.74 & 0.880 \\
\hline Q3. Increased employment opportunity & 3.83 & 0.921 & 3.71 & 0.871 \\
\hline Q4. Increased tax revenue & 3.40 & 0.885 & 3.61 & 0.861 \\
\hline Q5. Improved living condition & 3.73 & 0.827 & 3.69 & 0.950 \\
\hline Q6. Improved public facilities & 3.28 & 1.008 & 3.22 & 0.898 \\
\hline Q7. (R) Increased real estate cost & 3.29 & 1.112 & 3.08 & 0.839 \\
\hline Q8. (R) Increased living expense & 3.03 & 1.013 & 3.19 & 0.779 \\
\hline
\end{tabular}

As shown in Table 3, non-business operating local residents indicated higher mean than local merchants did toward items under the construct of "image implication". In items of positive direction, Local residents indicated higher mean for "Q1 enhanced local image", "Q2 enhanced reputation", "Q3 enhanced local pride", "Q5 increased confidence and pride", and "Q6 enhanced leisure facilities". In the only exception, local merchants were more concerned with "Q4 increased public security" than local residents did. In negative (reversed) items, local merchants indicated higher mean than local residents did for "Q7 (R) confrontation between tourists and locals", "Q8 (R) increased deterioration to the environment", "Q9 (R) negative effect on the local youths", and "Q10 (R) increased crimes". Because reversed items would be calculated from deduction of five, SPSS calculation would result higher mean by local residents than merchants in Q7 $(M=2.42>1.93), \mathrm{Q} 8(M=1.70>1.31), \mathrm{Q} 9(M$ $=2.55>2.25)$, and $\mathrm{Q} 10(M=2.55>2.23)$.

Table3. Respondents' attitudes toward “image implication”

\begin{tabular}{|l|c|c|c|c|}
\hline \multicolumn{1}{|c|}{ Items of measurement } & \multicolumn{2}{c|}{ Merchants } & \multicolumn{2}{c|}{ Residents } \\
\cline { 2 - 5 } & Mean & S.D. & Mean & S.D. \\
\hline Q1. Enhanced local image & 3.51 & 0.860 & 3.68 & 0.677 \\
\hline Q2. Enhanced reputation & 3.36 & 1.061 & 3.87 & 0.732 \\
\hline Q3. Enhanced local pride & 3.27 & 1.044 & 3.84 & 0.844 \\
\hline Q4. Increased public security & 3.43 & 0.947 & 3.10 & 1.199 \\
\hline Q5. Increased confidence and pride & 3.57 & 0.888 & 3.77 & 0.916 \\
\hline Q6. Enhanced leisure facilities & 3.13 & 1.212 & 3.66 & 0.926 \\
\hline Q7. (R) Confrontation between tourists and locals & 3.07 & 1.131 & 2.58 & 1.056 \\
\hline Q8. (R) Increased deterioration to the environment & 3.69 & 1.102 & 3.30 & 1.171 \\
\hline Q9. (R) Negative effect on the local youths & 2.75 & 0.960 & 2.45 & 0.967 \\
\hline Q10. (R) Increased crimes & 2.77 & 0.994 & 2.45 & 0.753 \\
\hline
\end{tabular}

The third construct, "environmental impact" is a negative dimension towards event hosting. As shown in Table 4, nine items were used to measure attitudes toward "environmental impact. With the exception of "Q7 increased traffic", local residents generally indicated higher mean on environmental impact items, "Q1 unbearable crowding", "Q2 deteriorated landscape", "Q3 negative effect on natural environment", "Q4 increased air pollution", "Q5 increased noise", "Q6 increased traffic", "Q8 
satisfies local politician's ambition", and "Q9 negative allocation of facility from crowd". Hence, it may be interpreted that local residents were more concerned with "environmental impact" associated with festive events than local merchants did.

Table4. Respondents' attitudes toward "environmental impact”

\begin{tabular}{|l|c|c|c|c|}
\hline \multicolumn{1}{|c|}{ Items of measurement } & \multicolumn{2}{c|}{ Merchants } & \multicolumn{2}{c|}{ Residents } \\
\cline { 2 - 5 } & Mean & S.D. & Mean & S.D. \\
\hline Q1. Unbearable crowding & 2.45 & 0.990 & 2.75 & 1.114 \\
\hline Q2. Deteriorated landscape & 2.65 & 1.007 & 3.18 & 1.085 \\
\hline Q3. Negative effect on natural environment & 2.76 & 0.898 & 3.32 & 0.938 \\
\hline Q4. Increased air pollution & 3.20 & 0.838 & 3.51 & 0.955 \\
\hline Q5. Increased noise & 3.04 & 0.992 & 3.36 & 0.931 \\
\hline Q6. Increased trash & 3.32 & 0.918 & 3.56 & 0.980 \\
\hline Q7. Increased traffic & 3.37 & 0.955 & 3.32 & 1.032 \\
\hline Q8. Satisfies local politician's ambition & 2.65 & 0.937 & 3.39 & 0.764 \\
\hline Q9. Negative allocation of facility from crowd & 2.71 & 0.912 & 2.97 & 0.688 \\
\hline
\end{tabular}

In the last construct, local merchants were more supportive of the music festival than local residents did. As shown in Table 5, local merchants felt "Q6 the festival's positives far outweigh the negatives overall" much more than local residents did $(M=4.12>3.43)$. Next greatest disparity of support towards the festival was identified in "Q2 support the development of the event" and "Q3 support more promotion of the event", where the mean by local merchants were 3.83 and 3.80 respectively as opposed to 3.32 and 3.30 by local residents. The rest of the items for the dimension of "local support" are: "Q1 support this festive event", "Q4 local officials should use this event to attract more tourists", and "Q5 the event should be used as the focal direction of the local's development".

Table5. Respondents' attitudes toward "local support"

\begin{tabular}{|l|c|c|c|c|}
\hline \multirow{2}{*}{ Items of measurement } & \multicolumn{2}{c|}{ Merchants } & \multicolumn{2}{c|}{ Residents } \\
\cline { 2 - 5 } & Mean & S.D. & Mean & S.D. \\
\hline Q1. I support this festive event & 3.57 & 0.841 & 3.53 & 0.788 \\
\hline Q2. I support the development of this event & 3.83 & 0.795 & 3.32 & 0.751 \\
\hline Q3. I support more promotion of this event & 3.80 & 0.838 & 3.30 & 0.919 \\
\hline Q4. Local officials should use this event to attract more tourists & 3.76 & 0.942 & 3.52 & 0.754 \\
\hline Q5. The event should be used as the focal direction of the local's development & 3.81 & 0.800 & 3.64 & 0.759 \\
\hline Q6. Overall, the event's positives far outweigh the negatives & 4.12 & 0.770 & 3.43 & 0.818 \\
\hline
\end{tabular}

Analysis of variance (ANOVA) was performed across all four dimensions associated with hosting of the music festival at Fulong Beach, Taiwan. As shown in Table 6, in the comparison between local merchants and residents, statistical significance was identified for the construct of "image implication" and "local support". Local residents indicated higher attitude towards "image implication" from the host of music festival than merchants $\operatorname{did}\left(M=3.5013>3.2280, p=.002^{* * * *}\right)$. On the other hand, local merchants were much more supportive of hosting the festival than residents $\operatorname{did}\left(M=3.8156>3.4156, p=.000^{* * *}\right)$. Although statistically insignificant, local residents tend to be more concerned with "environmental impact" than merchants do $(M=3.1429>2.9511, p=.062)$. As of "financial benefit" from the festival, local merchants and residents had similar attitude, 3.3350 and 3.3506 respectively.

Table6. Comparison of attitudes between local merchants and residents

\begin{tabular}{|l|l|l|l|c|c|c|}
\hline \multicolumn{2}{|c|}{ Attitude construct } & $\boldsymbol{N}$ & Mean & S.D. & F-value & Sig. \\
\hline \multirow{2}{*}{ Financial benefit } & Merchants & 75 & 3.3350 & 0.4628 & 0.039 & .843 \\
\cline { 2 - 5 } & Residents & 77 & 3.3506 & 0.5102 & & \\
\hline \multirow{2}{*}{ Image implication } & Merchants & 75 & 3.2280 & 0.6259 & \multirow{2}{*}{9.732} & $.002^{* *}$ \\
\cline { 2 - 5 } & Residents & 77 & 3.5013 & 0.4405 & & \\
\hline \multirow{2}{*}{ Environmental impact } & Merchants & 75 & 2.9511 & 0.6695 & \multirow{2}{*}{3.549} & .062 \\
\cline { 2 - 5 } & Residents & 77 & 3.1429 & 0.5935 & & \\
\hline Local support & Merchants & 75 & 3.8156 & 0.6859 & 13.696 & $.000^{* * *}$ \\
\cline { 2 - 5 } & Residents & 77 & 3.4156 & 0.6464 & & \\
\hline
\end{tabular}

${ }^{*} p<.05 ;{ }^{* *} p<.01 ;{ }^{* * *} p<.001$ 
Demographic differences were also identified through ANOVA for local merchants and local residents separately. Local merchants' demographic differences are illustrated from Table 7 to Table 10. Demographic differences of local residents are shown from Table 11 to Table 14. Statistical significance was identified by gender in Table 7 that female merchants felt the festival brought "financial benefit" to the community more than male merchants did $(M=3.5152>3.1935, p=$ $.002^{* * *}$ ). With no surprise, female merchants also were more "supportive" of the festival than their male counterparts did $\left(M=4.0152>3.6587, p=.024^{*}\right)$. Although statistically insignificant, female merchants also felt enhanced "image implication" from the event more than their male counterparts did $(M=3.3606>3.1238, p=.104)$. However, female merchants also were more concerned about "environmental impact" than their male counterparts did $(M=3.1044>2.8307, p=.079)$. In Table 8, no statistical significance was identified by local merchants' age group.

Table7. ANOVA of merchants' attitudes toward festival (by gender)

\begin{tabular}{|l|l|l|l|c|c|c|}
\hline \multicolumn{2}{|c|}{ Attitude construct } & $\boldsymbol{N}$ & Mean & $\boldsymbol{S}$.D. & F-value & Sig. \\
\hline \multirow{2}{*}{ Financial benefit } & Male & 42 & 3.1935 & 0.4735 & 10.018 & $.002^{* *}$ \\
\cline { 2 - 5 } & Female & 33 & 3.5152 & 0.3850 & & \\
\hline \multirow{2}{*}{ Image implication } & Male & 42 & 3.1238 & 0.5872 & 2.706 & .104 \\
\cline { 2 - 6 } & Female & 33 & 3.3606 & 0.6571 & & \\
\hline \multirow{2}{*}{ Environmental impact } & Male & 42 & 2.8307 & 0.7024 & 3.179 & .079 \\
\cline { 2 - 5 } & Female & 33 & 3.1044 & 0.6009 & & \\
\hline \multirow{2}{*}{ Local support } & Male & 42 & 3.6587 & 0.7297 & 5.279 & $.024^{* *}$ \\
\cline { 2 - 5 } & Female & 33 & 4.0152 & 0.5764 & & \\
\hline
\end{tabular}

${ }^{*} p<.05 ;{ }^{* *} p<.01 ;{ }^{* * *} p<.001$

Table8. ANOVA of merchants' attitudes toward festival (by age group)

\begin{tabular}{|c|c|c|c|c|c|c|}
\hline \multicolumn{2}{|c|}{ Attitude construct } & $N$ & Mean & S.D. & F-value & Sig. \\
\hline \multirow[t]{3}{*}{ Financial benefit } & AG (1) & 13 & 3.2212 & 0.5976 & \multirow[t]{3}{*}{0.901} & \multirow[t]{3}{*}{.411} \\
\hline & $\mathrm{AG}(2)$ & 37 & 3.3142 & 0.3960 & & \\
\hline & AG (3) & 25 & 3.4250 & 0.4801 & & \\
\hline \multirow[t]{3}{*}{ Image implication } & $\mathrm{AG}(1)$ & 13 & 3.2615 & 0.7066 & \multirow[t]{3}{*}{0.022} & \multirow[t]{3}{*}{.978} \\
\hline & $\mathrm{AG}(2)$ & 37 & 3.2189 & 0.6358 & & \\
\hline & $\mathrm{AG}(3)$ & 25 & 3.2240 & 0.5925 & & \\
\hline \multirow[t]{3}{*}{ Environmental impact } & $\mathrm{AG}(1)$ & 13 & 2.9744 & 0.8192 & \multirow[t]{3}{*}{2.026} & \multirow[t]{3}{*}{.139} \\
\hline & $\mathrm{AG}(2)$ & 37 & 2.8078 & 0.5724 & & \\
\hline & AG (3) & 25 & 3.1511 & 0.6938 & & \\
\hline \multirow[t]{3}{*}{ Local support } & $\mathrm{AG}(1)$ & 13 & 3.5128 & 0.8987 & \multirow[t]{3}{*}{1.694} & \multirow[t]{3}{*}{.191} \\
\hline & $\mathrm{AG}(2)$ & 37 & 3.8423 & 0.6490 & & \\
\hline & AG (3) & 25 & 3.9333 & 0.5912 & & \\
\hline
\end{tabular}

Age Group (1) = under 30 years old; $(2)=30$ to 50 years old; $(3)=$ over 50 years old

${ }^{*} p<.05 ;{ }^{* *} p<.01 ;{ }^{* * *} p<.001$

In Table 9, merchants with a "college education" felt more strongly of "financial benefit" than merchants with an education of "high school or less" felt of the festival, where post hoc by LSD showed a difference of 0.28588 with $p=.011^{*}$. It must be noted that the number of sample from merchants with a "post graduate education" (5.3\%) is far less than other educational groups, hence no statistical significance by merchants of "post graduate education" across all four dimensions. Merchants with a "college education" also were more concerned with "environmental impact" than those with an education of "high school or less" did, where post hoc by LSD showed a difference of 0.87374 with $p=.011^{*}$. Merchants with a "college education" were more "supportive" of the festive event than those with an education of "high school or less" did, where post hoc by LSD showed a difference of 0.70833 with $p=.045^{*}$. Although statistically insignificant, merchants with higher education felt more highly of "image implication" than merchants with less education $(M=3.7250$ > $3.2296>3.1818$ from respondents of "post gradate", "4-year college", and "high school or less" educations, respectively). 
Comparative Analysis of Attitudes toward a Festive Event between Local Merchants and Residents Music Festival at Fulong Beach, Taiwan

Table9. ANOVA of merchants'attitudes toward festival (by education group)

\begin{tabular}{|c|c|c|c|c|c|c|}
\hline \multicolumn{2}{|c|}{ Attitude construct } & $N$ & Mean & S.D. & F-value & Sig. \\
\hline \multirow[t]{3}{*}{ Financial benefit } & EG (1) & 44 & 3.2188 & 0.4747 & \multirow[t]{3}{*}{3.606} & \multirow[t]{3}{*}{$.032^{*}$} \\
\hline & EG (2) & 27 & 3.5046 & 0.3960 & & \\
\hline & EG (3) & 4 & 3.4688 & 0.4607 & & \\
\hline \multirow[t]{3}{*}{ Image implication } & EG (1) & 44 & 3.1818 & 0.6259 & \multirow[t]{3}{*}{1.396} & \multirow[t]{3}{*}{.254} \\
\hline & EG (2) & 27 & 3.2296 & 0.6420 & & \\
\hline & EG (3) & 4 & 3.7250 & 0.3403 & & \\
\hline \multirow[t]{3}{*}{ Environmental impact } & EG (1) & 44 & 2.8207 & 0.6318 & \multirow[t]{3}{*}{3.899} & \multirow[t]{3}{*}{$.025^{*}$} \\
\hline & EG (2) & 27 & 3.0535 & 0.6641 & & \\
\hline & EG (3) & 4 & 3.6944 & 0.6566 & & \\
\hline \multirow[t]{3}{*}{ Local support } & EG (1) & 44 & 3.6667 & 0.6914 & \multirow[t]{3}{*}{3.292} & \multirow[t]{3}{*}{$.043^{*}$} \\
\hline & EG (2) & 27 & 3.9753 & 0.6022 & & \\
\hline & EG (3) & 4 & 4.3750 & 0.7979 & & \\
\hline
\end{tabular}

Education Group (1) = high school or less; (2) = 4-year college; (3) = post graduate

${ }^{*} p<.05 ;{ }^{* *} p<.01 ;{ }^{* * *} p<.001$

In Table 10, merchants with an annual income of "more than NT\$600,000" were more "supportive of the festival" than merchants who annually earn "between NT\$400,000 and NT\$600,000" felt of hosting the festival, where post hoc by LSD showed a difference of 0.71032 with $p=.001^{* *}$. At the same time, merchants with an annual income of "between NT\$400,000 and NT\$600,000" were more "supportive of the festival" than merchants who annually earn "less than NT\$400.000" felt, where post hoc by LSD showed a difference of 0.65207 with $p=.002^{* *}$. Although statistically insignificant across the other three dimensions, merchants who earned more felt more strongly of "financial benefit" and "image implication" from the festival than those who earned less. However, merchants who earned "less than NT $\$ 400,000$ annually" were more concerned about "environmental impact" than their higher-earning counterparts did.

Table10. ANOVA of merchants' attitudes toward festivals (by income group)

\begin{tabular}{|c|c|c|c|c|c|c|}
\hline \multicolumn{2}{|c|}{ Attitude construct } & $N$ & Mean & S.D. & F-value & Sig. \\
\hline \multirow[t]{3}{*}{ Financial benefit } & IG (1) & 14 & 3.0982 & 0.6471 & \multirow[t]{3}{*}{2.683} & \multirow[t]{3}{*}{.075} \\
\hline & IG (2) & 31 & 3.4355 & 0.3548 & & \\
\hline & IG (3) & 30 & 3.3417 & 0.4367 & & \\
\hline \multirow[t]{3}{*}{ Image implication } & IG (1) & 14 & 3.1214 & 0.4949 & \multirow[t]{3}{*}{.506} & \multirow[t]{3}{*}{.605} \\
\hline & IG (2) & 31 & 3.3097 & 0.7190 & & \\
\hline & IG (3) & 30 & 3.1933 & 0.5842 & & \\
\hline \multirow[t]{3}{*}{ Environmental impact } & IG (1) & 14 & 3.1032 & 0.8217 & \multirow[t]{3}{*}{.443} & \multirow[t]{3}{*}{.644} \\
\hline & IG (2) & 31 & 2.9068 & 0.5796 & & \\
\hline & IG (3) & 30 & 2.9259 & 0.6926 & & \\
\hline \multirow[t]{3}{*}{ Local support } & IG (1) & 14 & 3.2619 & 0.8861 & \multirow[t]{3}{*}{6.506} & \multirow[t]{3}{*}{$.003^{*}$} \\
\hline & IG (2) & 31 & 3.9140 & 0.5592 & & \\
\hline & IG (3) & 30 & 3.9722 & 0.5841 & & \\
\hline
\end{tabular}

Income Group $(1)=$ under NT\$400,000; (2) = NT\$40,000 - NT\$600,000; (3) = over NT\$600,000

${ }^{*} p<.05 ;{ }^{* *} p<.01 ;{ }^{* * *} p<.001$

Table11. ANOVA of residents' attitudes toward festival (by gender)

\begin{tabular}{|c|c|c|c|c|c|c|}
\hline \multicolumn{2}{|c|}{ Attitude construct } & $N$ & Mean & S.D. & F-value & Sig. \\
\hline \multirow[t]{2}{*}{ Financial benefit } & Male & 37 & 3.2297 & 0.5579 & \multirow[t]{2}{*}{4.168} & \multirow[t]{2}{*}{$.045^{*}$} \\
\hline & Female & 40 & 3.4625 & 0.4396 & & \\
\hline \multirow[t]{2}{*}{ Image implication } & Male & 37 & 3.4405 & 0.4180 & \multirow[t]{2}{*}{1.361} & \multirow[t]{2}{*}{.247} \\
\hline & Female & 40 & 3.5575 & 0.4585 & & \\
\hline \multirow[t]{2}{*}{ Environmental impact } & Male & 37 & 3.1291 & 0.5865 & \multirow[t]{2}{*}{.039} & \multirow[t]{2}{*}{.844} \\
\hline & Female & 40 & 3.1556 & 0.5878 & & \\
\hline \multirow[t]{2}{*}{ Local support } & Male & 37 & 3.3243 & 0.6678 & \multirow[t]{2}{*}{1.428} & \multirow[t]{2}{*}{.236} \\
\hline & Female & 40 & 3.5000 & 0.6225 & & \\
\hline
\end{tabular}

${ }^{*} p<.05 ;{ }^{* *} p<.01 ;{ }^{* * *} p<.001$ 
Comparative Analysis of Attitudes toward a Festive Event between Local Merchants and Residents Music Festival at Fulong Beach, Taiwan

Statistical significance was identified by gender in Table 11 that female residents felt more strongly of "financial benefit" from the host of festival than male residents did $\left(M=3.4625>3.2297, p=.045^{*}\right)$. Although statistically insignificant, female residents felt more strongly of "image implication" and "local support" than male residents did. Female residents also were also more concerned about "environmental impact" than male residents did. In Table 12, no statistical significance was identified by local residents' age group.

Table12. ANOVA of residents' attitudes toward festival (by age group)

\begin{tabular}{|c|c|c|c|c|c|c|}
\hline \multicolumn{2}{|c|}{ Attitude construct } & $N$ & Mean & S.D. & F-value & Sig. \\
\hline \multirow[t]{3}{*}{ Financial benefit } & $\mathrm{AG}(1)$ & 30 & 3.4000 & 0.6241 & \multirow[t]{3}{*}{0.226} & \multirow[t]{3}{*}{.798} \\
\hline & $\mathrm{AG}(2)$ & 37 & 3.3209 & 0.4395 & & \\
\hline & $\mathrm{AG}(3)$ & 10 & 3.3125 & 0.3964 & & \\
\hline \multirow[t]{3}{*}{ Image implication } & $\mathrm{AG}(1)$ & 30 & 3.5533 & 0.4840 & \multirow[t]{3}{*}{0.370} & \multirow[t]{3}{*}{.692} \\
\hline & $\mathrm{AG}(2)$ & 37 & 3.4595 & 0.4058 & & \\
\hline & $\mathrm{AG}(3)$ & 10 & 3.5000 & 0.4570 & & \\
\hline \multirow[t]{3}{*}{ Environmental impact } & $\mathrm{AG}(1)$ & 30 & 3.1111 & 0.6346 & \multirow[t]{3}{*}{0.204} & \multirow[t]{3}{*}{.816} \\
\hline & $\mathrm{AG}(2)$ & 37 & 3.1862 & 0.5909 & & \\
\hline & AG (3) & 10 & 3.0778 & 0.4059 & & \\
\hline \multirow[t]{3}{*}{ Local support } & $\mathrm{AG}(1)$ & 30 & 3.4556 & 0.7878 & \multirow[t]{3}{*}{0.272} & \multirow[t]{3}{*}{.762} \\
\hline & $\mathrm{AG}(2)$ & 37 & 3.3604 & 0.5794 & & \\
\hline & $\mathrm{AG}(3)$ & 10 & 3.5000 & 0.4006 & & \\
\hline
\end{tabular}

Age Group (1) = under 30 years old; $(2)=30$ to 50 years old; $(3)=$ over 50 years old

${ }^{*} p<.05 ;{ }^{* *} p<.01 ;{ }^{* * *} p<.001$

In Table 13, residents with an education of "high school or less" felt more strongly of "image implication" than "college-educated" residents felt of hosting the festival, where post hoc by LSD showed a difference of 0.23009 with $p=.028^{*}$. It must be noted that the number of sample from residents with a "post graduate education" $(2.6 \%)$ is far less than other educational groups, hence no statistical significance by residents of "post graduate" education across all four dimensions. Nonetheless, residents with "high school or less" education felt more strongly toward "financial benefit", "image implication", and "local support" regarding the festival than residents of other educational groups did. Residents with "post graduate" education were more concerned with "environmental impact" than residents of other educational groups did. In Table 14, no statistical significance was identified by local residents' income group.

Table13. ANOVA of residents' attitudes toward festival (by education group)

\begin{tabular}{|c|c|c|c|c|c|c|}
\hline \multicolumn{2}{|l|}{ Attitude construct } & $N$ & Mean & S.D. & $F$-value & Sig \\
\hline \multirow[t]{3}{*}{ Financial benefit } & EG (1) & 27 & 3.4120 & 0.5502 & \multirow[t]{3}{*}{1.087} & \multirow[t]{3}{*}{.343} \\
\hline & EG (2) & 48 & 3.3359 & 0.4907 & & \\
\hline & EG (3) & 2 & 2.8750 & 0.1768 & & \\
\hline \multirow[t]{3}{*}{ Image implication } & EG (1) & 27 & 3.6593 & 0.4684 & \multirow[t]{3}{*}{3.413} & \multirow[t]{3}{*}{$.038^{*}$} \\
\hline & EG (2) & 48 & 3.4292 & 0.4068 & & \\
\hline & EG (3) & 2 & 3.1000 & 0.1414 & & \\
\hline \multirow[t]{3}{*}{ Environmental impact } & EG (1) & 27 & 3.2593 & 0.5504 & \multirow[t]{3}{*}{1.024} & \multirow[t]{3}{*}{.364} \\
\hline & EG (2) & 48 & 3.0694 & 0.6063 & & \\
\hline & EG (3) & 2 & 3.3333 & 0.1571 & & \\
\hline \multirow[t]{3}{*}{ Local support } & EG (1) & 27 & 3.4120 & 0.5502 & \multirow[t]{3}{*}{0.429} & \multirow[t]{3}{*}{.653} \\
\hline & EG (2) & 48 & 3.3359 & 0.4907 & & \\
\hline & EG (3) & 2 & 2.8750 & 0.1768 & & \\
\hline
\end{tabular}

Education Group $(1)=$ high school or less; $(2)=4$-year college; $(3)=$ post graduate

${ }^{*} p<.05 ;{ }^{* *} p<.01 ;{ }^{* * *} p<.001$

Table14. ANOVA of residents' attitudes toward festival (by income group)

\begin{tabular}{|l|l|c|c|c|c|c|}
\hline \multicolumn{2}{|c|}{ Attitude construct } & $\boldsymbol{N}$ & Mean & S.D. & F-value & Sig. \\
\cline { 1 - 6 } Financial benefit & IG (1) & 38 & 3.3487 & 0.6241 & 0.597 & .553 \\
\cline { 2 - 6 } & IG (2) & 32 & 3.3945 & 0.3916 & & \\
\cline { 2 - 5 } & IG (3) & 7 & 3.1607 & 0.2249 & & \\
\hline
\end{tabular}


Comparative Analysis of Attitudes toward a Festive Event between Local Merchants and Residents Music Festival at Fulong Beach, Taiwan

\begin{tabular}{|c|c|c|c|c|c|c|}
\hline \multirow[t]{3}{*}{ Image implication } & IG (1) & 38 & 3.5237 & 0.4745 & \multirow[t]{3}{*}{2.253} & \multirow[t]{3}{*}{.112} \\
\hline & IG (2) & 32 & 3.5469 & 0.3902 & & \\
\hline & IG (3) & 7 & 3.1714 & 0.3773 & & \\
\hline \multirow[t]{3}{*}{ Environmental impact } & IG (1) & 38 & 3.1228 & 0.6410 & \multirow[t]{3}{*}{0.185} & \multirow[t]{3}{*}{.832} \\
\hline & IG (2) & 32 & 3.1389 & 0.5494 & & \\
\hline & IG (3) & 7 & 3.2698 & 0.4438 & & \\
\hline \multirow[t]{3}{*}{ Local support } & IG (1) & 38 & 3.4298 & 0.7460 & \multirow[t]{3}{*}{0.025} & \multirow[t]{3}{*}{.975} \\
\hline & IG (2) & 32 & 3.3958 & 0.5801 & & \\
\hline & IG (3) & 7 & 3.4286 & 0.3450 & & \\
\hline
\end{tabular}

Income Group $(1)=$ under NT\$400,000; $(2)=$ NT\$40,000 - NT\$600,000; (3) = over NT\$600,000

${ }^{*} p<.05 ;{ }^{* *} p<.01 ;{ }^{* * *} p<.001$

\section{CONCLUSION}

Music festival occurs annually on Fulong Beach, Taiwan. Both positive and negative impacts associated with the event would stay with the local community. Local residents with or without business interest may differ in their attitude toward this festive event. Hence, the study took survey on both the local business persons (merchants) and non-business operating residents. Their attitudes were evaluated across four dimensions: "financial benefit", "image implication", "environmental impact", and "local support". It was identified that local residents felt more strongly about "image implication" than local merchants did. However, local merchants felt more highly of "local support" than local residents did. Local residents were more concerned with "environmental impact" associated with the festival than local merchants did, albeit statically insignificant. Local merchants and residents had about the same attitude towards "financial benefit" associated with the festival.

By demographic profile of merchants, it was identified that female merchants felt more highly of "financial benefit" than their male counterparts did regarding the festival. Female merchants also agreed more than their male counterparts did about "local support" of the festival. Merchants with higher education (college or post graduate) felt more highly of "financial benefit", "image implication", and "local support" than their less-educated counterparts did. However, highly educated merchants were also more concerned about "environmental impact" associated with the festival. By merchants" income level, those with higher annual income were more "supportive" about the host of the festival. Merchants' age had no bearing on the difference of attitudes toward any of the four dimensions associated with the festive event.

By demographic profile of non-business operating local residents, female residents felt more highly of "financial benefit" than male residents did. Local residents who were less-educated felt more strongly of "image implication" than those with higher education felt for the festival. Both "age" and "income" had no bearing on the difference of attitudes across all four dimensions toward the music festival by the local residents. In summary, future event organizers should pay more attention to non-business operating local residents because they are more concerned about "environmental impact" associated with events, and they are less supportive of event hosting. Females of both merchants and residents are more concerned with "environmental impact" associated with festivals. At the same time, females also feel more strongly of the "image implication" and "local support" toward the festival. Hence, future organizers should also address "environmental impact" with females more.

\section{REFERENCES}

[1] Andersson, T.D., \& Lundberg, E. (2013). Commensurability and sustainability: Triple impact assessments of a tourism event. Tourism Management, 37, 99-109.

[2] Brown, M.D., Var, T., \& Lee, S. (2002). Messina Hof Wine and Jazz Festival: An economic impact analysis. Tourism Economics, 8(3), 273-279.

[3] Collins, A., \& Cooper, C. (2017). Measuring and managing the environmental impact of festivals: The contribution of the Ecological Footprint. Journal of Sustainable Tourism, 25(1), 148-162.

[4] Chen, S.C. (2011). Residents' perceptions of the impact of major annual tourism events in Macao: Cluster analysis. Journal of Convention \& Event Tourism, 12(2), 106-128.

[5] Delamere, T.A. (2001). Development of a scale to measure resident attitudes toward the social impacts of community festivals, Part II. Verification of the scale. Event Management, 7(1), 25-38. 
[6] Fredline, L., Jago, L., \& Deery, M. (2002). The development of a generic scale to measure the social impacts of events. Event Management, 2, 23-37.

[7] Getz, D. (1991). Festivals, Special Events, and Tourism. New York: Van Nostrand Reinhold.

[8] Getz, D. (2010). The nature and scope of festival studies. International Journal of Event Management Research, 5(1), 1-47.

[9] Gibson, C., \& Stewart, A. (2009). Reinventing rural places: The extent and impact of festivals in rural and regional Australia. Wollongong, Australia: University of Wollongong.

[10] Gibson, C.R., \& Wong, C. (2011). Greening rural festivals: Ecology, sustainability and human-nature relations. In C.R. Gibson \& J. Connell (Eds.), Festival Places - Rural Australia (pp. 92-105), Bristol, UK: Channel View Publications.

[11] Gursoy, D., Kim, K., \& Uysal, M. (2004). Perceived impacts of festivals and special events by organizers: An extension and validation. Tourism Management, 25(2), 171-181.

[12] Jackson, L.A. (2008). Residents' perceptions of the impacts of special event tourism. Journal of Place Management and Development, 1(3), 240-255.

[13] Kim, H., Borges, M.C., \& Chon, J. (2006). Impacts of environmental values on tourism motivation: The case of FICA, Brazil. Tourism Management, 27(5), 957-967.

[14] Kim, S.S., \& Petrick, J.F. (2005). Residents' perceptions on impacts of the FIFA 2002 World Cup: The case of Seoul as a host city. Tourism Management, 26(1), 25-38.

[15] Kim, K., \& Uysal, M. (2003). Perceived social-economic impacts of festivals and events among organizers. Journal of Hospitality \& Leisure Marketing, 10(3/4), 159-171.

[16] Laing, J., \& Frost, W. (2010). How green was my festival: Exploring challenges and opportunities associated with staging green events. International Journal of Hospitality Management, 29(2), 261-267.

[17] Long, P.T., \& Perdue, R.R. (1990). The economic impact of rural festivals and special events: Assessing the spatial distribution of expenditures. Journal of Travel Research, 28(4), 10-14.

[18] Mair, J., \& Whitford, M. (2013). An exploration of events research: Event topics, themes and emerging trends. International Journal of Events and Festival Management, 4(1), 6-30.

[19] Mayfield, T., \& Crompton, J. (1995). Development of an instrument for identifying community reasons for staging a festival, Journal of Travel Research, 33(3), 37-44.

[20] Small, K., Edwards, D., \& Sheridan, L. (2005). A flexible framework for evaluating the socio-cultural impacts of a (small) festival. International Journal of Event Management Research, 1(1), 66-77.

[21] Song, H.J., Lee, C.K., Kang, S.K., \& Boo, S.J. (2012). The effect of environmentally friendly perceptions on festival visitors' decision-making process using an extended model of goal-directed behavior. Tourism Management, 33(6), 1417-1428.

[22] Tang, S.Y., Tang, C.P., \& Lo, C.W.H. (2005). Public participation and environmental impact assessment in Mainland China and Taiwan: Political foundations of environmental management. The Journal of Development Studies, 41(1), 1-32.

[23] Uysal, M., Gahan, L, \& Martin, B. (1993). An examination of event motivations: A case study. Festival Management and Event Tourism, 1(1), 5-10.

[24] Yolal, M., Cetinel, F., \& Uysal, M. (2009). An examination of festival motivation and perceived benefits relationship: Eskisehir International Festival. Journal of Convention \& Event Tourism, 10(4), 276-291.

[25] Zhou, J.Y., \& Ap, J. (2009). Residents' perceptions towards the impacts of the Beijing 2008 Olympic Games. Journal of Travel Research, 48(1), 78-91.

Citation: Chung-Tai Wu, Huey-Ling Liao. "Comparative Analysis of Attitudes toward a Festive Event between Local Merchants and Residents - Music Festival at Fulong Beach, Taiwan ". International Journal of Research in Tourism and Hospitality (IJRTH), vol 4, no. 2, 2018, pp. 36-47. doi: http://dx.doi.org/10.20431/2455-0043.0402005.

Copyright: (C) 2018 Authors. This is an open-access article distributed under the terms of the Creative Commons Attribution License, which permits unrestricted use, distribution, and reproduction in any medium, provided the original author and source are credited. 